\title{
The Tribal Farmers' Perceptions about Weeds Affecting the Productivity of Scented Rice Cultivars in Jashpur District of Chhattisgarh, India
}

\author{
Subodh Kumar Pradhan", M. A. Khan and S. Narbaria \\ Department of Agricultural Extension, Indira Gandhi Krishi Vishwavidyalaya, \\ Raipur-492012, Chhattisgarh, India \\ *Corresponding author
}

\begin{tabular}{|l|}
\hline Ke y w o r d s \\
$\begin{array}{l}\text { Scented Rice, Weed } \\
\text { control, } \\
\text { Productivity, Yield } \\
\text { loss }\end{array}$ \\
\hline Article Info \\
\hline $\begin{array}{l}\text { Accepted: } \\
\text { 10 November } 2019 \\
\text { Available Online: } \\
10 \text { December } 2019\end{array}$ \\
\hline
\end{tabular}

\section{A B S T R A C T}

Chhattisgarh state is considered as one of the centers of origin and evolution of rice and is blessed with enormous funds of rice variability. Scented rice constitutes a special group of rice and the cultivation of scented rice varieties is one of the oldest practices. Looking to the changing consumer preferences, the demand of the scented rice is increasing day by day. The availability of scented rice in comparison to the demand is meager due to low productivity and susceptibility to several biotic and abiotic stresses. Weed is one of the important factor caused reduction in the productivity of scented rice. In this perspective the present study was undertaken in Jashpur district of Chhattisgarh with data collected from 144 scented rice growing farmers. The findings shows that, majority of the respondents perceived that wild rice (Oryza nivara), Sarbana/Samna (Echinochloa spp.), Motha (Cyperus spp.), Kankauwa (Commelina bengalensis), Bhorandi/Badauri (Ischaemum rugosum), Machhli ankh (Panicum repens) and Masariya (Corchorus spp.), in order are the major weeds causing yield loss in scented rice varieties. Accordingly it was found that the severity of Echinochloa spp. was highest. The yield loss caused due to these weeds is up to 75 per cent. Remarkably, it was found that almost all farmers follows the traditional weed management practices and only few scented rice growers were using chemicals for the management of weeds. It shows a complex situation which has to be overcome by incorporating strategic extension approaches so that the effective weed management can be done in scented rice cultivation to increase the productivity and profitability.

\section{Introduction}

Rice (Oryza sativa L.) is the most important staple food crop for more than half of the world's population, including regions of high population density and rapid growth. It provides about 21 per cent of the total calorie intake of the world population. Because of growing population, the demand for rice is expected to increase in the coming decades. Rice plays an important role in our national food security and is a means of livelihood for millions of rural households. However, to meet this demand the crop should perform to its full potential. Certain factors tend to restrict the crop's potential performance. Weeds are 
one of the major factors responsible for low yield of rice. Weeds reduce the crop yield and deteriorate the quality of produce and hence reduce the market value of the turnout.

Early emergence of weeds along with crop seedlings and their rapid growth result severe crop-weed competition. Among the various reasons for low productivity, weeds alone are reported to cause $50-60 \%$ reduction in grain yield (Duary et al., 2005).

They use the soil fertility, available moisture and nutrients, compete for space and light with crop plants, which result in yield reduction. Scented rice cultivation is emerging as a new economic pursuit for the paddy farmers in some localities of the country and also in Chhattisgarh. Furthermore, weed competition is severe in scented paddy culture, in view of its early slow growth rates and it may be exacerbated by sub-optimal population densities. Maintenance of optimal population density is, therefore, critical for optimizing crop productivity. Climate change will also affect the weed communities in the rice based cropping system. Effect of weed growth on yield suggested losses in the range 28-74 per cent in rice.

The availability of scented rice in comparison to the demand is meager due to low productivity and susceptibility to several biotic and a-biotic stresses. Infestation of weeds is one of the important factor caused reduction in the productivity of scented rice. In this perspective the present study was undertaken in Jashpur district of Chhattisgarh with the following objectives:-

To determine the occurrence, severity and control measures of major weeds in scented rice varieties, and

To determine the yield loss in scented rice varieties due to various weeds.

\section{Materials and Methods}

The study was carried out in Jashpur district of Chhattisgarh state. The study is based on the primary data, collected from the total 4 blocks namely Bagicha, Duldula, Jashpur and Pharsabahar which were purposively selected, because of higher area under scented rice cultivation. Three villages were selected purposively from each block and 12 respondents from each village were randomly selected, thus 144 scented rice growing farmers were selected for the study. For selection of respondents, a comprehensive list of scented rice growing farmers was prepared with the help of village sarpanch and agriculture extension personnel of respective village. A well structured and pre-tested interview schedule was used to collect data from the respondents by personal interview method.

\section{Results and Discussion}

\section{Productivity of scented rice varieties}

The findings towards the average productivity of scented rice varieties are presented in Table 1. The data revealed that maximum productivity $(24.68 \mathrm{q} / \mathrm{ha})$ was obtained from Kala jeera and Kasturi, followed by Jau phool and Dubraj (24.64 q/ha). In case of average productivity, the highest average productivity (22.23 q/ha) was obtained from Shakkar chini, followed by Laung phool (21.10 q/ha), Kasturi (20.25 q/ha), Basta bhog, Basmati and Nakul bhog (19.76 q/ha), Dubraj (19.53 q/ha), these higher producing scented rice varieties were grown by limited number of respondents, Jeera phool (19.18 q/ha), Jau phool (18.98 q/ha), Kala jeera (18.44 q/ha), Gundari bhog (17.30 q/ha), Tulsi manjar (17.25 q/ha) and Rani kajal (15.44 q/ha) were also performing at par with other scented rice varieties grown by the respondents. It was found that average productivity of other scented rice varieties like 
Vishnu bhog, Hanuman bhog, Badshah bhog, Begam bhog, Sona phool, Bangal bhog, Pooja etc. was $17.58 \mathrm{q} / \mathrm{ha}$ which was grown by small number of respondents. The data also revealed that in case of minimum productivity, 10.50 q/ha was gained from Rani kajal, followed by Tulsi manjar with minimum productivity of $15.07 \mathrm{q} / \mathrm{ha}$. Although there were slight difference in minimum and maximum productivity of different rice varieties but the average productivity was found at par among different rice varieties.

\section{Occurrence, severity, yield loss and control measures of the weeds}

Weeds are one of the major biotic factors which affect the productivity of rice. In this study occurrence of weeds, their severity, yield loss and control measures are taken for the study.

\section{Occurrence of weeds}

The findings on the occurrence of weeds are presented in the Table 2. The data revealed that majority of the respondent $(83.33 \%)$ perceived that wild rice (Oryza spp.) is the major weed followed by Sarbana/Samna (Echinochloa spp.) and Motha (Cyperus spp.) as reported by 77.78 and 75.69 per cent of the respondents, respectively.

Kankauwa (Commelina bengalensis), Bhorandi/Badauri (Ischaemum rugosum), Machhli ankh (Panicum repens), Masariya (Corchorus spp.) were also reported to be important weeds occurred in scented rice cultivation as perceived by the $61.81,57.64$, 50.00 and 43 per cent of the respondents, respectively. About 42 per cent of the respondents reported that Chilbili (Aeschynomene spp.), 25.69 per cent reported
Banmirchi (Sphenoclea zeylanica), 18.06 per cent reported wild mint/Akalkara (Spilanthes acmella), 12.50 per cent reported Ghodghas (Leersia hexandra), 11.81 per cent reported Sunsunia/Chaupatia (Marsilea minuta) and 9.72 per cent of the respondents reported that Ghoda kesari (Scirpus juncoides) were also important weeds occurred in scented rice. About 8 per cent of the respondents perceived that Jalkumbhi (Monochoria vaginalis) was occurred in the fields of scented rice.

Occurrence, severity, yield loss and control measures for weeds

The findings related to the occurrence, severity, yield loss and control measures relevant with weeds are presented in the Table 3. Almost all of the respondents reported that most of the weeds were regularly occurred in the field of scented rice, while often occurred weeds were Banmirchi (Sphenoclea zeylanica) and Chilbili (Aeschynomene spp.). No weed was found to be rarely occurred. The data revealed that as per the farmers' perception, severity of Sarbana/Samna (Echinochloa spp.) was highest $(75.00 \%)$, followed by wild rice (Oryza nivara) and Machhli ankh (Panicum repens) as reported by the 64.17 and 58.33 per cent of the respondents, respectively. It was found that severity of Masariya (Corchorus spp.) was medium (77.42\%) and low severe weed was Banmirchi (Sphenoclea zeylanica) reported by 90.91 per cent of the respondents. Regarding the yield losses caused due to these weeds, all of the respondents perceived that most of the weeds caused yield loss up to the 25 per cent, except Sarbana/Samna (Echinochloa spp.), wild rice (Oryza nivara), Chilbili (Aeschynomene spp.), similarly Sridevi et al., 2013 found that it reduces the grain yield up to the extent of 32 per cent. 
Table.1 Productivity status of different scented rice varieties cultivated by the respondents

\begin{tabular}{|c|c|c|c|c|c|}
\hline S. No. & Varieties & Respondents adopted** & \multicolumn{3}{|c|}{ Productivity (q/ha) } \\
\cline { 3 - 6 } & & $(\mathbf{\%})$ & Min. & Avrg. & Max. \\
\hline $\mathbf{1}$ & Jau phool & 46.53 & 15.56 & 18.98 & 24.64 \\
\hline $\mathbf{2}$ & Jeera phool & 26.39 & 15.76 & 19.18 & 23.39 \\
\hline $\mathbf{3}$ & Kala jeera & 11.80 & 16.15 & 18.44 & 24.68 \\
\hline $\mathbf{4}$ & Gundari bhog & 6.25 & 15.91 & 17.30 & 22.55 \\
\hline $\mathbf{5}$ & Kasturi & 4.17 & 15.31 & 20.25 & 24.68 \\
\hline $\mathbf{6}$ & Shakkar chini & 2.78 & 18.20 & 22.23 & 23.94 \\
\hline $\mathbf{7}$ & Laung phool & 4.17 & 19.76 & 21.10 & 23.04 \\
\hline $\mathbf{8}$ & Basta bhog & 2.08 & 16.06 & 19.76 & 23.86 \\
\hline $\mathbf{9}$ & Tulsi manjar & 3.47 & 15.07 & 17.25 & 21.66 \\
\hline $\mathbf{1 0}$ & Basmati & 1.39 & 15.44 & 19.76 & 23.47 \\
\hline $\mathbf{1 1}$ & Dubraj & 2.78 & 18.82 & 19.53 & 24.64 \\
\hline $\mathbf{1 2}$ & Rani kajal & 1.39 & 10.50 & 15.44 & 21.00 \\
\hline $\mathbf{1 3}$ & Nakul bhog & 2.08 & 17.29 & 19.76 & 23.05 \\
\hline $\mathbf{1 4}$ & Other* & 18.75 & - & 17.58 & - \\
\hline & Total & Cumulative average productivity & $\mathbf{1 8 . 2 3}$ q/ha & \\
\hline
\end{tabular}

* Other scented varieties like Vishnu bhog, Hanuman bhog, Badshah bhog, Begam bhog, Sona phool, Bangal bhog, Pooja etc. **Data are based on multiple responses

Table.2 Distribution of respondents with respect to major weeds occurred in scented rice

\begin{tabular}{|c|l|c|c|}
\hline Rank & Occurring weeds & Frequency* & Percentage \\
\hline I & Wild Rice (Oryza nivara) & 120 & 83.33 \\
\hline II & Sarbana/Samna (Echinochloa spp.) & 112 & 77.78 \\
\hline III & Motha(Cyperus spp.) & 109 & 75.69 \\
\hline IV & Kankauwa (Commelina bengalensis) & 89 & 61.81 \\
\hline V & Bhorandi/Badauri (Ischaemum rugosum) & 83 & 57.64 \\
\hline VI & Machhli ankh (Panicum repens) & 72 & 50.00 \\
\hline VII & Masariya (Corchorus spp.) & 62 & 43.06 \\
\hline VIII & Chilbili(Aeschynomene spp.) & 61 & 42.36 \\
\hline IX & Banmirchi (Sphenoclea zeylanica) & 37 & 25.69 \\
\hline X & Wild mint (Spilanthes acmella) & 26 & 18.06 \\
\hline XI & Ghodghas (Leersia hexandra) & 18 & 12.50 \\
\hline XII & Sunsunia/Chaupatia (Marsilea minuta) & 17 & 11.81 \\
\hline XIII & Ghoda kesari (Scirpus juncoides) & 14 & 9.72 \\
\hline XIV & Jalkumbhi (Monochoria vaginalis) & 11 & 7.64 \\
\hline
\end{tabular}

*Data are based on multiple responses 
Table.3 Distribution of respondents according to occurrence, severity, yield loss and control measures pertaining to weeds

\begin{tabular}{|c|c|c|c|c|c|c|c|c|c|c|c|c|c|c|c|c|c|c|c|}
\hline \multirow{3}{*}{$\begin{array}{l}\mathbf{S} \\
\mathbf{N}\end{array}$} & \multirow[t]{3}{*}{ Particulars } & \multicolumn{18}{|c|}{ Weeds } \\
\hline & & \multicolumn{2}{|c|}{$\begin{array}{l}\text { Wild Rice } \\
\text { (Oryza spp.) } \\
(\mathrm{n}=120)\end{array}$} & \multicolumn{2}{|c|}{$\begin{array}{c}\text { Echinochloa } \\
\text { spp. } \\
(\mathrm{n}=112)\end{array}$} & \multicolumn{2}{|c|}{$\begin{array}{c}\text { Aeschynomene } \\
\text { spp. } \\
(\mathrm{n}=61)\end{array}$} & \multicolumn{2}{|c|}{$\begin{array}{c}\text { Cyperus } \\
\text { spp. } \\
(\mathrm{n}=109)\end{array}$} & \multicolumn{2}{|c|}{$\begin{array}{l}\text { Panicum } \\
\text { repens } \\
(\mathrm{n}=72)\end{array}$} & \multicolumn{2}{|c|}{$\begin{array}{l}\text { Ischaemum } \\
\text { rugosum } \\
(\mathrm{n}=83)\end{array}$} & \multicolumn{2}{|c|}{$\begin{array}{l}\text { Commelina } \\
\text { bengalensis } \\
\quad(n=89)\end{array}$} & \multicolumn{2}{|c|}{$\begin{array}{l}\text { Sphenoclea } \\
\text { zeylanica } \\
(\mathrm{n}=37)\end{array}$} & \multicolumn{2}{|c|}{$\begin{array}{c}\text { Corchorus } \\
\text { spp. } \\
(\mathrm{n}=62)\end{array}$} \\
\hline & & $\mathrm{f}$ & $\%$ & $\mathrm{f}$ & $\%$ & $\mathrm{f}$ & $\%$ & $\mathrm{f}$ & $\%$ & $\mathrm{f}$ & $\%$ & $\mathrm{f}$ & $\%$ & $\mathrm{f}$ & $\%$ & $\mathrm{f}$ & $\%$ & $\mathrm{f}$ & $\%$ \\
\hline 1 & $\begin{array}{l}\text { Occurrence } \\
\text { Regularly } \\
\text { Often } \\
\text { Sometimes } \\
\text { Rarely }\end{array}$ & $\begin{array}{c}120 \\
0 \\
0 \\
0\end{array}$ & $\begin{array}{c}100.0 \\
0.00 \\
0.00 \\
0.00\end{array}$ & $\begin{array}{c}112 \\
0 \\
0 \\
0\end{array}$ & $\begin{array}{l}100.0 \\
0.00 \\
0.00 \\
0.00\end{array}$ & $\begin{array}{c}60 \\
1 \\
0 \\
0\end{array}$ & $\begin{array}{c}98.36 \\
1.64 \\
0.00 \\
0.00\end{array}$ & $\begin{array}{c}109 \\
0 \\
0 \\
0\end{array}$ & $\begin{array}{c}100.0 \\
0.00 \\
0.00 \\
0.00\end{array}$ & $\begin{array}{c}72 \\
0 \\
0 \\
0\end{array}$ & $\begin{array}{c}100.0 \\
0.00 \\
0.00 \\
0.00\end{array}$ & $\begin{array}{c}83 \\
0 \\
0 \\
0\end{array}$ & $\begin{array}{c}100.0 \\
0.00 \\
0.00 \\
0.00\end{array}$ & $\begin{array}{c}89 \\
0 \\
0 \\
0\end{array}$ & $\begin{array}{c}100.0 \\
0.00 \\
0.00 \\
0.00\end{array}$ & $\begin{array}{c}36 \\
1 \\
0 \\
0\end{array}$ & $\begin{array}{l}97.30 \\
2.70 \\
0.00 \\
0.00\end{array}$ & $\begin{array}{c}62 \\
0 \\
0 \\
0\end{array}$ & $\begin{array}{c}100.0 \\
0.00 \\
0.00 \\
0.00\end{array}$ \\
\hline 2 & $\begin{array}{l}\text { Severity } \\
\text { High } \\
\text { Medium } \\
\text { Low } \\
\text { Nil }\end{array}$ & $\begin{array}{c}77 \\
41 \\
2 \\
0\end{array}$ & $\begin{array}{c}64.17 \\
34.16 \\
1.67 \\
0.00\end{array}$ & $\begin{array}{c}84 \\
24 \\
4 \\
0\end{array}$ & $\begin{array}{c}75.00 \\
21.43 \\
3.57 \\
0.00\end{array}$ & $\begin{array}{c}20 \\
40 \\
1 \\
0\end{array}$ & $\begin{array}{c}32.79 \\
65.57 \\
1.64 \\
0.00\end{array}$ & $\begin{array}{c}2 \\
42 \\
65 \\
0\end{array}$ & $\begin{array}{c}1.84 \\
38.53 \\
59.63 \\
0.00\end{array}$ & $\begin{array}{c}42 \\
20 \\
10 \\
0\end{array}$ & $\begin{array}{c}58.33 \\
27.78 \\
13.89 \\
0.00\end{array}$ & $\begin{array}{c}27 \\
50 \\
6 \\
0\end{array}$ & $\begin{array}{c}32.53 \\
60.24 \\
7.23 \\
0.00\end{array}$ & $\begin{array}{c}2 \\
34 \\
53 \\
0\end{array}$ & $\begin{array}{c}2.25 \\
38.20 \\
59.55 \\
0.00\end{array}$ & $\begin{array}{c}1 \\
15 \\
25 \\
0\end{array}$ & $\begin{array}{c}2.70 \\
40.54 \\
67.56 \\
0.00\end{array}$ & $\begin{array}{c}10 \\
48 \\
4 \\
0\end{array}$ & $\begin{array}{c}16.13 \\
77.42 \\
6.45 \\
0.00\end{array}$ \\
\hline 3 & $\begin{array}{l}\text { Yield loss } \\
0-25 \% \\
26-50 \% \\
51-75 \% \\
76-100 \%\end{array}$ & $\begin{array}{c}76 \\
44 \\
0 \\
0\end{array}$ & $\begin{array}{c}63.33 \\
36.67 \\
0.00 \\
0.00\end{array}$ & $\begin{array}{c}38 \\
70 \\
4 \\
0\end{array}$ & $\begin{array}{c}33.93 \\
62.50 \\
3.57 \\
0.00 \\
\end{array}$ & $\begin{array}{c}35 \\
26 \\
0 \\
0\end{array}$ & $\begin{array}{c}57.38 \\
42.62 \\
0.00 \\
0.00\end{array}$ & $\begin{array}{c}109 \\
0 \\
0 \\
0\end{array}$ & $\begin{array}{c}100.0 \\
0.00 \\
0.00 \\
0.00\end{array}$ & $\begin{array}{c}50 \\
22 \\
0 \\
0\end{array}$ & $\begin{array}{c}69.44 \\
30.56 \\
0.00 \\
0.00\end{array}$ & $\begin{array}{c}76 \\
7 \\
0 \\
0\end{array}$ & $\begin{array}{c}91.57 \\
8.43 \\
0.00 \\
0.00\end{array}$ & $\begin{array}{c}89 \\
0 \\
0 \\
0\end{array}$ & $\begin{array}{c}100.0 \\
0.00 \\
0.00 \\
0.00\end{array}$ & $\begin{array}{c}37 \\
0 \\
0 \\
0\end{array}$ & $\begin{array}{c}100.0 \\
0.00 \\
0.00 \\
0.00\end{array}$ & $\begin{array}{c}54 \\
7 \\
1 \\
0\end{array}$ & $\begin{array}{c}87.10 \\
11.29 \\
1.61 \\
0.00\end{array}$ \\
\hline 4 & $\begin{array}{l}\text { Control Measures } \\
\text { Apply } \\
\text { Not apply }\end{array}$ & $\begin{array}{c}120 \\
0\end{array}$ & $\begin{array}{c}100.0 \\
0.00\end{array}$ & $\begin{array}{c}112 \\
0\end{array}$ & $\begin{array}{c}100.0 \\
0.00\end{array}$ & $\begin{array}{c}61 \\
0\end{array}$ & $\begin{array}{c}100.0 \\
0.00\end{array}$ & $\begin{array}{l}109 \\
0.00\end{array}$ & $\begin{array}{c}100.0 \\
0.00\end{array}$ & $\begin{array}{c}72 \\
0.00\end{array}$ & $\begin{array}{c}100.0 \\
0.00\end{array}$ & $\begin{array}{c}83 \\
0\end{array}$ & $\begin{array}{c}100.0 \\
0.00\end{array}$ & $\begin{array}{c}89 \\
0\end{array}$ & $\begin{array}{c}100.0 \\
0.00\end{array}$ & $\begin{array}{c}37 \\
0\end{array}$ & $\begin{array}{c}100.0 \\
0.00\end{array}$ & $\begin{array}{c}62 \\
0\end{array}$ & $\begin{array}{c}100.0 \\
0.00\end{array}$ \\
\hline 5 & $\begin{array}{l}\text { Type of control } \\
\text { measure use* } \\
\text { Traditional } \\
\text { Chemical }\end{array}$ & $\begin{array}{c}120 \\
0\end{array}$ & $\begin{array}{c}100.0 \\
0.00\end{array}$ & $\begin{array}{c}112 \\
0\end{array}$ & $\begin{array}{c}100.0 \\
0.00\end{array}$ & $\begin{array}{c}61 \\
0\end{array}$ & $\begin{array}{c}100.0 \\
0.00\end{array}$ & $\begin{array}{c}109 \\
0\end{array}$ & $\begin{array}{c}100.0 \\
0.00\end{array}$ & $\begin{array}{c}72 \\
0\end{array}$ & $\begin{array}{c}100.0 \\
0.00\end{array}$ & $\begin{array}{c}83 \\
0\end{array}$ & $\begin{array}{c}100.0 \\
0.00\end{array}$ & $\begin{array}{c}87 \\
2\end{array}$ & $\begin{array}{c}97.75 \\
2.25\end{array}$ & $\begin{array}{c}35 \\
2\end{array}$ & $\begin{array}{c}94.60 \\
5.40\end{array}$ & $\begin{array}{c}62 \\
0\end{array}$ & $\begin{array}{c}100.0 \\
0.00\end{array}$ \\
\hline
\end{tabular}

*Data are based on multiple responses 
Table.4 Distribution of respondents according to control measure applied for weeds management

\begin{tabular}{|c|c|c|c|}
\hline S. No. & Control measures & Frequency* & Percentage \\
\hline $\mathbf{1}$ & Traditional methods & 144 & 100.00 \\
\hline $\mathbf{2}$ & Chemical methods & 2 & 1.39 \\
\hline
\end{tabular}

*Data are based on multiple responses

Majority of the respondents $(62.50 \%)$ perceived that Sarbana/Samna (Echinochloa spp.) as a major weed caused yield loss between 26 to 50 per cent. Chilbili (Aeschynomene spp.) and wild rice (Oryza nivara) were also causing $25-50$ per cent yield loss as reported by the 42.86 and 36.67 per cent of the respondents.. It was also found that some of the respondents perceived that Sarbana/samna (Echinochloa spp.) and Masariya (Corchorus spp.) weeds were causing sometimes yield loss up to 75 per cent and the result supported by Singh et al., (2012) reported that weeds in many fields are capable of reducing yields by more than 80 per cent.

Regarding application of control measures, cent per cent of the respondents used control measures for all the weeds. All of the respondents reported that they were used traditional control measures for controlling all weeds (These measures includes hand weeding, biasi, ploughing between rows etc.).

Regarding chemical control, 5.40 per cent of the respondents used chemical control for Banmirchi (Sphenoclea zeylanica) and only 2.25 per cent of the respondents used chemical control for Kankauwa (Commelina bengalensis). It was found that there were no any chemical control measures applied by the respondents for most of the narrow leaf weeds. The present findings are in line with the findings of Shori (2011), who revealed that Cyperus spp. and Echinochloa colona L. were the most serious weeds in puddled rice. It causes 10 per cent and 8.35 per cent yield losses.

\section{Control measures for weeds}

The findings related to control measures for weeds are presented in the Table 4. Regarding application of control measures, cent per cent of the respondents used control measures for weeds. Control measures applied for weeds reduce the yield loss and increase yield, the study of Mahajan et al., (2012) reported that weed control improve rice yield by 15-30 per cent. All of the respondents used traditional control measures for weed management. Regarding chemical control, only 1.39 per cent of the respondents used chemical control for weed in the fields of scented rice.

From the above findings it can be concluded that in case of weeds as per the farmers' perception, wild rice (Oryza nivara), Sarbana/Samna (Echinochloa spp.), Motha (Cyperus spp.), Kankauwa (Commelina bengalensis), Bhorandi/Badauri (Ischaemum rugosum), Machhli ankh (Panicum repens) and Masariya (Corchorus spp.) were regularly occurred weeds than others and severity of Echinochloa spp. was highest. It was also found that Echinochloa spp. and Corchorus spp. caused yield losses up to 75 per cent.

Regarding application of control measures, both traditional and chemical control measure were used to control weeds in scented rice cultivation, but mostly traditional control measures were used. So it may be some strategies which have to be overcome by incorporating strategic extension approaches so that the weed management can be done effectively to increase the productivity and profitability from scented rice cultivation. 


\section{References}

Anonymous. 2012. Model training course on rice production technology. Directorate of Extension Services, IGKV, Raipur (C.G.). pp 1-119.

Duary, B., Hossain A. and Mondal, D. C. 2005. Integrated weed management in direct seeded dry sown rice in lateritic belt of West Bengal. Indian journal of Weed Science 37 (1 \& 2): 101-102.

Jacob, D. and Syriac, E. K. 2005. Performance of transplanted scented rice (Oryza sativa L.) under different spacing and weed management regimes in southern Kerala. Journal of Tropical Agriculture, 43 (1-2): 71-73.

Jagtap, D. N., Pawar, P. B., Sutar, M. W., Jadhav, M. S., Pinjari, S. S. and Meshram, N. A. 2018. Effect of weed management practices on Kharif riceA review. Journal of Research in Weed Science 1 (2): 37-47.

Mahajan, G., Singh, S. and Chauhan, B. S. 2012. Impact of climate change on weeds in the rice-wheat cropping system, Current Science, 102(9): 12541255.

Parameswari Y. S., Srinivas, A., Ram Prakash, T. and Narendar, G. 2014. Effect of different crop establishment methods on rice (Oryza sativa L.) growth and yield - A review, Agriculture Reviews, 35 (1): 74-77.

Shori, R. K. 2011. Attitude of farmers regarding adoption of control measure practices of various weeds of rice crop in Dhamtari district of Chhattisgarh state. M.Sc. (Ag.) Thesis, IGKV, Raipur (C.G.).

Singh, A., Kaur,R., Kang, J.S. and Singh, G. 2012. Weed dynamics in rice-wheat cropping system, Global Journal of Biology, Agriculture and Health Sciences, 1(1):7-16.

Sridevi, V., Jeyaraman, S., Chinnusamy, C. and v. Chellamuthu, V. 2013. Weed management in lowland rice (Oryza sativa L.) ecosystem- A review, International Journal of Agricultural Science and Research (IJASR), 3(3): 13-22.

\section{How to cite this article:}

Subodh Kumar Pradhan, M. A. Khan and Narbaria, S. 2019. The Tribal Farmers' Perceptions about Weeds Affecting the Productivity of Scented Rice Cultivars in Jashpur District of Chhattisgarh. Int.J.Curr.Microbiol.App.Sci. 8(12): 989-995.

doi: https://doi.org/10.20546/ijcmas.2019.812.127 